\title{
The importance of updated criteria in breeding soundness examination of commercial Nellore bulls for the herd reproductive improvement
}

[Importância de critérios atualizados na avaliação andrológica de touros Nelore a campo para a evolução reprodutiva do rebanho]

\author{
J.H.W. Diniz', A.C.B. Teixeira ${ }^{1}$, J.A.N. Riveros ${ }^{1}$, R.F.G. Peres $^{2}$, D.Q. Fonseca ${ }^{3}$, \\ E.C.R. Cunha ${ }^{3}$, V.M.T. Vilela ${ }^{1}$, D.F. Silva ${ }^{1}$, A.M.P. Leo ${ }^{1}$, \\ R.C.F.T. Palhares ${ }^{1}$, L.Z. Oliveira ${ }^{1 *}$
}

${ }^{1}$ Escola de Veterinária - Universidade Federal de Minas Gerais - Belo Horizonte, MG

${ }^{2}$ Nelore Paranã - Fazenda Eldorado - Iaciara, GO

${ }^{3}$ AgroSB - Palmas, TO

\begin{abstract}
The aim of this work was to compare results of breeding soundness examination (BSE) of Nellore bulls $(n=1257)$ according to evaluation criteria from two different classification tables (traditional-Table1 used since 1997 and an updated-Table2-proposed in 2020). Data were separated into 3 categories: questionable animals in Table1 and Table2 (Q1Q2), animals approved in Table1 and questionable in Table2 (A1Q2) and animals approved in Table1 and Table2 (A1A2). BSE parameters were submitted to ANOVA $(\mathrm{P}<005)$, according to age groups. Higher $(\mathrm{P}<0.0001)$ scrotal perimeter $(\mathrm{PE})$ were observed in A1A2 category (18$24 \mathrm{~m}=33.4 \pm 2.4 \mathrm{~cm} ; 24-36 \mathrm{~m}=34.5 \pm 2.2 \mathrm{~cm} ; 36-48 \mathrm{~m}=36.6 \pm 1.7 \mathrm{~cm} ;>48 \mathrm{~m}=38.6 \pm 1.7 \mathrm{~cm})$ compared to A1Q2 $(18-24 \mathrm{~m}=29.05 \pm 0.98 \mathrm{~cm} ; 24-36 \mathrm{~m}=30.3 \pm 0.6 \mathrm{~cm} ; 36-48 \mathrm{~m}=32.9 \pm 1.0 \mathrm{~cm} ;>48 \mathrm{~m}=34.8 \pm 1.0 \mathrm{~cm})$ and to Q1Q2 $(24-36 \mathrm{~m}=26.8 \pm 2.0 \mathrm{~cm} ; 36-48 \mathrm{~m}=30.0 \pm 0.1 \mathrm{~cm} ;>48 \mathrm{~m}=31.3 \pm 1.1 \mathrm{~cm})$, for all age groups. At the age of 3648months $(\mathrm{Q} 1 \mathrm{Q} 2=2.7 \pm 0.3 ; \quad \mathrm{A} 1 \mathrm{Q} 2=3.2 \pm 0.3 ; \quad \mathrm{A} 1 \mathrm{~A} 2=3.3 \pm 0.6)$ and $>48$ months $(\mathrm{Q} 1 \mathrm{Q} 2=3.0 \pm 0.4$; $\mathrm{A} 1 \mathrm{Q} 2=3.3 \pm 0.5 ; \mathrm{A} 1 \mathrm{~A} 2=3.4 \pm 0.5)$, animals with better andrological classifications presented higher $(\mathrm{P}<0.05)$ body condition score (BCS). Additionally, at age $>48 \mathrm{~m}$, higher sperm Motility $(\mathrm{P}=0.0250)$ and Vigor $(\mathrm{P}=0.0335)$ were observed in animals $\mathrm{A} 1 \mathrm{Q} 2$ (Mot=55.5 $\pm 14.7 \% ; \quad \mathrm{V}=3.21 \pm 0.82)$ and $\mathrm{A} 1 \mathrm{~A} 2$ (Mot=55.8 $\pm 12.2 \% ; \mathrm{V}=3.23 \pm 0.81$ ) compared to Q1Q2 (Mot=50.2 $\pm 17.4 \% ; \mathrm{V}=2.77 \pm 0.82)$. It was concluded that bulls approved using strict selection criteria demonstrated higher PE and BCS, regardless of the age. The utilization of updated classification tables is highly recommended for further reproductive potential development of Nellore bulls in the field.
\end{abstract}

Keywords: andrology, bovine, fertility, scrotal perimeter, classification tables

\section{RESUMO}

O objetivo deste estudo foi comparar os resultados obtidos no exame andrológico a campo de touros Nelore $(n=1257)$ de acordo com os critérios de avaliação de duas tabelas de classificação (uma tabela tradicional - tabela 1 - proposta em 1997 e uma nova tabela atualizada - tabela 2 - proposta em 2020). Os dados foram separados em três categorias: animais questionáveis nas tabelas 1 e 2 (Q1Q2), animais aprovados na tabela 1 e questionáveis na tabela 2 (AlQ2) e animais aprovados nas tabelas 1 e 2 (AlA2). Os parâmetros foram submetidos à análise de variância $(P<0,05)$, por faixa etária. Observou-se maior

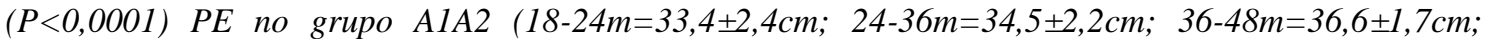
$>48 \mathrm{~m}=38,6 \pm 1,7 \mathrm{~cm})$ em comparação ao grupo AlQ2 $(18-24 \mathrm{~m}=29,05 \pm 0,98 \mathrm{~cm} ; 24-36 \mathrm{~m}=30,3 \pm 0,6 \mathrm{~cm} ; 36$ $48 \mathrm{~m}=32,9 \pm 1,0 \mathrm{~cm} ;>48 \mathrm{~m}=34,8 \pm 1,0 \mathrm{~cm})$ e este maior $(P<0,0001)$ que $Q 1 Q 2(24-36 \mathrm{~m}=26,8 \pm 2,0 \mathrm{~cm}$; 36 $48 \mathrm{~m}=30,0 \pm 0,1 \mathrm{~cm} ;>48 \mathrm{~m}=31,3 \pm 1,1 \mathrm{~cm})$ em todas as idades. Nas faixas etárias $36-48 \mathrm{~m}(Q 1 Q 2=2,7 \pm 0,3$; $A 1 Q 2=3,2 \pm 0,3 ; A 1 A 2=3,3 \pm 0,6)$ e $>48 m(Q 1 Q 2=3,0 \pm 0,4 ; A 1 Q 2=3,3 \pm 0,5 ; A 1 A 2=3,4 \pm 0,5)$, animais com melhor classificação andrológica apresentaram melhor $(P<0,05)$ escore de condição corporal $(E C C)$.

Recebido em 27 de agosto de 2020

Aceito em 27 de outubro de 2020

*Autor para correspondência (corresponding author)

E-mail: leticiazoccolaro@yahoo.com.br 
Adicionalmente, na idade $>48 \mathrm{~m}$, maiores motilidade $(P=0,0250)$ e vigor $(P=0,0335)$ foram observados

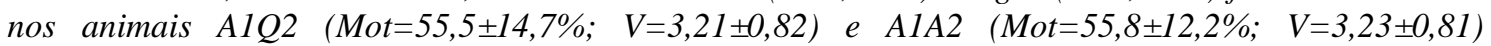
comparados aos animais Q1Q2 (Mot=50,2 $\pm 17,4 \% ; V=2,77 \pm 0,82$ ). Concluiu-se que touros aprovados na tabela com critérios mais rigorosos de classificação (tabela 2) apresentaram maior PE e ECC, independentemente da idade. Assim, a utilização de tabelas classificatórias atualizadas é fundamental para maior desenvolvimento do potencial reprodutivo de touros Nelore a campo.

Palavras-chave: andrologia, bovino, fertilidade, perímetro escrotal, tabela classificatória

\section{INTRODUCTION}

Selecting bulls with high reproductive potential is recognized as important, given their effective impact on livestock production efficiency. Genetic improvement programs aim to increase livestock productivity by increasing the frequency of desirable genes (Siqueira et al., 2013) and scrotal perimeter (PE) remains an important selection criteria for bulls from beef cattle production systems. Since PE is a reproductive parameter of practical assessment, highly repeatable and moderate-to-high heritability (Bergmann et al., 1996; Pereira et al., 2002; Siqueira et al., 2013; Fonseca et al., 2019) this characteristic received great attention of Nellore breed researchers in the last decades (Pinto et al., 1989; Fonseca et al., 1997; Silva et al., 2002; Viu et al., 2006; Siqueira et al., 2013; Fonseca et al., 2020).

According to Siqueira et al. (2013) the selection to PE improvement does not determine direct economic benefit, but it results in reproductive precocity and increased weight gain of the herd (higher birth weight, weaning weight and yearling weight). In addition, PE is also correlated with important reproductive traits of female (age at first partum and probability of pregnancy) and male offspring (testicular volume and sperm concentration) (Bergman et al., 1996; Eler et al., 1996, 2004; Ahmad et al., 2010; Siqueira et al., 2013; Ayala et al., 2016). Moreover, the importance of bioeconomic impact of bull breeding soundness examination (BSE) in cowcalf systems is clear, since they have substantial impact on the genetics of the herd (Menegassi et al., 2011).

For Nellore breed, several bull classifications tables are recommended in order to select animals with greater reproductive capacity (Fonseca et al., 1997; Vale-Filho, 2001, 2010; Fonseca et al., 2020). However, the lack of updated information regarding those selection criteria can interfere on breed development and genetic improvement. Hence, the aim of this work was to assess a largescale BSE of a commercial beef cattle farm and to compare the results obtained from bull selection criteria according to two classification tables for Nellore breed (a traditional table classification proposed in 1997 and an updated table, newly proposed in 2020).

\section{MATERIAL AND METHODS}

In the present study, field data of BSE from 1257 Nellore bulls (Bos taurus indicus) from the same commercial group of beef cattle production (Pará, Brazil) was utilized. All animals were pasture raised under extensive system and natural breeding regime. Bulls were maintained in pasture of Brachiaria brizantha or Brachiaria decumbens, supplemented with mineral salt and free access to water. On the day of BSE, the age of each animal was recorded, and the body condition score (BCS) was measured, always by the same experienced technician, on a 1 to 5 scale (where $1=$ very thin and $5=$ obese; Hougton $e t$ al., 1990).

The BSE consisted of reproductive clinical examination of each animal, including assessment of PE using a measuring tape in centimeters (Willet and Ohms, 1975) and assessment of semen quality $($ sperm motility $=$ Mot; vigor $=\mathrm{V}$; sperm morphological defects as major defects $=\mathrm{DMa}$, minor defects $=$ dme and total sperm defects $=$ TDE; Blom, 1973), according to the Brazilian College of Animal Reproduction (Manual..., 2013). Electroejaculation (Eletrojet $₫$, Eletrovet, São Paulo, SP, Brazil) was utilized for semen collection.

Immediately after each semen collection, microscopic analysis was performed. Hence, $10 \mu \mathrm{L}$ of semen was deposited between slide and cover slip (warmed at $37^{\circ} \mathrm{C}$ ) and evaluated under optical microscope with $100 \mathrm{x}$ magnification (model ICS standard 25, Zeiss, Oberkochen, 
Germany) for sperm motility assessment (Mot, expressed as a percentage) and vigor ( $\mathrm{V}$, expressed on a 0 to 5 scale). Another semen aliquot was used for sperm morphology assessment. Sperm morphology was assessed by optical microscope with 1000X magnification (model ICS standard 25, Zeiss, Oberkochen, Germany). The staining preparation was performed according to the manufacturer's instructions of fast panotic commercial kit (Laborclin ${ }^{\circledR}$ Ltda., Pinhais, PR, Brazil). After staining preparation, the slides were air-dried prior to microscopic immersion evaluation, performed with 1000x magnification. A total of 200 cells per sample was evaluated.

Animals with genetic disorders or severe clinical alterations were considered unsatisfactory and were excluded from the data utilized for this study (once a cause of fertility disorder was considered as a definitive diagnosis and/or of genetic origin the animal was discarded from this study). Hence, animals that were classified as unsatisfactory (considered "inapt") are not included in BSE data of the present study. Then, four age groups were established (18 to 24 months, 24 to 36,36 to 48 and above 48 months) and bulls that had their reproductive parameters from BSE fully evaluated $(\mathrm{n}=1257)$ were classified as Questionable or Approved (Excellent, Very good or Good) according to a traditional table (Table 1) described by Fonseca et al. (1997). Also, the same data $(n=1257)$ was used to classify the animals as Questionable or Approved (Excellent, Very good or Good) according to a new (updated) table (Table 2) described by Fonseca et al. (2020). Finally, the data were separated into 3 groups: questionable animals in Table 1 and in Table 2 (Q1Q2), animals approved in Table 1 and questionable in Table 2 (A1Q2) and animals approved in Table 1 and in Table 2 (A1A2).

In order to analyze the results grouped according to the BSE classification tables, the variables (mean \pm standard deviation) of the groups Q1Q2, A1Q2 and A1A2 were compared separately by age (18 to 24 months, 24 to 36 months, 36 to 48 months and 48 months). Andrological parameters (BCS, PE, Mot, V, DMa, dme, TDE) were submitted to analysis of variance and differences among groups were analyzed using the Tukey test (Graphpad Instat; Version 3.06, Graphpad) where $\mathrm{P}<0.05$ was considered significant.

Table 1. Classification table for Nellore bulls (Bos indicus), based on scrotal perimeter (PE) and semen characteristics proposed by Fonseca et al. (1997)

\begin{tabular}{|c|c|c|c|c|}
\hline \multirow{2}{*}{ Parameters } & \multicolumn{4}{|c|}{ Classification } \\
\hline & Excellent & Very good & Good & Questionable \\
\hline \multicolumn{5}{|l|}{ 1-Sperm Motility } \\
\hline Vigor & 5 & $4<5$ & $3<4$ & $<3$ \\
\hline Progressive Motility (\%) & $\geq 75$ & $60<75$ & $30<60$ & $<30$ \\
\hline Points awarded & $21-25$ & $16<21$ & $10<16$ & $<10$ \\
\hline \multicolumn{5}{|l|}{ 2-Sperm Morphology } \\
\hline Major defects (\%) & $\leq 5$ & $>5-10$ & $>10-20$ & $>20$ \\
\hline Total defects (\%) & $\leq 10$ & $>10-15$ & $>15-30$ & $>30$ \\
\hline Points awarded & $30-35$ & $25<30$ & $15<25$ & $<15$ \\
\hline \multicolumn{5}{|l|}{ 3-Scrotal Perimeter $(\mathrm{cm})$} \\
\hline \multicolumn{5}{|l|}{ Age in months } \\
\hline 12 to $<18$ & $\geq 26.0$ & $24.0<26.0$ & $21.5<24.0$ & $<21.5$ \\
\hline 18 to $<24$ & $\geq 31.5$ & $28.5<31.5$ & $26.0<28.5$ & $<26.0$ \\
\hline 24 to $<36$ & $\geq 35.0$ & $32.0<35.0$ & $29.0<32.0$ & $<29.0$ \\
\hline 36 to $<48$ & $\geq 37.0$ & $33.5<37.0$ & $30.5<33.5$ & $<30.5$ \\
\hline$>48$ & $\geq 39.0$ & $36.0<39.0$ & $33.0<36.0$ & $<33.0$ \\
\hline Points awarded & $35-40$ & $25<35$ & $15<25$ & $<15$ \\
\hline TOTAL POINTS & $86-100$ & $66<86$ & $40<66$ & $<40$ \\
\hline
\end{tabular}

According to Fonseca et al. (1997), a score is given according to sperm characteristics and scrotal perimeter. Animals are classified as Satisfactory (excellent, very good or good) or as Questionable (animals not recommended for reproduction) after BSE. 
Table 2. Classification table for Nellore bulls (Bos indicus), based on scrotal perimeter (PE) and semen characteristics proposed by Fonseca et al. (2020) - A new and updated proposition

\begin{tabular}{|c|c|c|c|c|}
\hline \multirow{2}{*}{ Parameters } & \multicolumn{4}{|c|}{ Classification } \\
\hline & Excellent & Very good & Good & Questionable \\
\hline \multicolumn{5}{|l|}{ 1-Sperm Motility } \\
\hline Progressive Motility (\%) & $\geq 75$ & $60<75$ & $50<60$ & $<50$ \\
\hline Vigor & 5 & $4<5$ & $3<4$ & $<3$ \\
\hline Points awarded & $21-25$ & $16<21$ & $10<16$ & $<10$ \\
\hline \multicolumn{5}{|l|}{ 2-Sperm Morphology } \\
\hline Major defects $(\%)$ & $\leq 3$ & $4-10$ & $11-15$ & $>15$ \\
\hline Total defects (\%) & $\leq 10$ & $11-15$ & $15-30$ & $>30$ \\
\hline Points awarded & $30-35$ & $25<30$ & $20<25$ & $<20$ \\
\hline \multicolumn{5}{|l|}{ 3-Scrotal Perimeter $(\mathrm{cm})$} \\
\hline 12 to $<18$ month & $\geq 33.5$ & $31.5 \leq 33.4$ & $29.5 \leq 31.4$ & $\leq 29.4$ \\
\hline 18 to $<24$ month & $\geq 34.0$ & $32.0 \leq 33.9$ & $30.5 \leq 31.9$ & $\leq 30.4$ \\
\hline 24 to $<36$ month & $\geq 35.5$ & $33.0 \leq 35.4$ & $31.5 \leq 32.9$ & $\leq 31.4$ \\
\hline 36 to $<48$ month & $\geq 38.5$ & $36.5 \leq 38.4$ & $35.0 \leq 36.4$ & $\leq 34.9$ \\
\hline$>48$ month & $\geq 39.5$ & $38.0 \leq 39.4$ & $36.5 \leq 37.9$ & $\leq 36.4$ \\
\hline Points awarded & $35-40$ & $30<35$ & $15<30$ & 0 \\
\hline TOTAL POINTS & $86-100$ & $71<86$ & $45<71$ & $<45$ \\
\hline
\end{tabular}

According to Fonseca et al. (2020), a new score is given according to sperm characteristics and scrotal perimeter. Animals are classified as Satisfactory (excellent, very good or good) or as Questionable (animals not recommended for reproduction) after BSE.

\section{RESULTS AND DISCUSSION}

In order to demonstrate the importance of updated selection criteria during bull BSE for genetic improvement of commercial beef farms, we evaluated andrological parameters of Nellore bulls in natural breeding regime. Then, we compared the evaluation criteria based on two classification tables from different decades, in order to verify differences in the mean parameters achieved in each assessed characteristic. It was observed that, regardless of the age, overall BCS was $3.33 \pm 0.93 \quad(n=1257)$ and Table 3 demonstrates the effect of different classification criteria on PE and BCS means at different age groups.

Table 3. Mean ( \pm Standard Deviation) of scrotal perimeter $(\mathrm{PE})$ and body condition score (BCS; scale from 1 to 5) of 1257 Nellore bulls submitted to field andrological examination based on classification tables proposed by Fonseca et al. 1997, 2020

\begin{tabular}{cccccc}
\hline Age group & Parameter & Q1Q2 & A1Q2 & A1A2 & P value \\
\hline 18 to 24 months & PE & $\mathrm{X}$ & $29.05 \pm 0.98 \mathrm{~cm}^{\mathrm{a}}$ & $33.4 \pm 2.4 \mathrm{~cm}^{\mathrm{b}}$ & $\mathrm{P}<0.0001$ \\
& BCS & $\mathrm{X}$ & $2.7 \pm 0.2^{\mathrm{A}}$ & $2.9 \pm 0.4^{\mathrm{B}}$ & $\mathrm{P}=0.0640$ \\
& $\mathrm{~N}$ & 0 & 10 & 34 & \\
\hline 24 to 36 months & $\mathrm{PE}$ & $26.8 \pm 2.0 \mathrm{~cm}^{\mathrm{a}}$ & $30.3 \pm 0.6 \mathrm{~cm}^{\mathrm{b}}$ & $34.5 \pm 2.2 \mathrm{~cm}^{\mathrm{c}}$ & $\mathrm{P}<0.0001$ \\
& $\mathrm{BCS}$ & $3.0 \pm 0.3^{\mathrm{B}}$ & $3.3 \pm 0.3^{\mathrm{A}}$ & $3.1 \pm 0.5^{\mathrm{AB}}$ & $\mathrm{P}=0.0819$ \\
& $\mathrm{~N}$ & 6 & 27 & 78 & \\
\hline 36 to 48 months & $\mathrm{PE}$ & $30.0 \pm 0.1 \mathrm{~cm}^{\mathrm{a}}$ & $32.9 \pm 1.0 \mathrm{~cm}^{\mathrm{b}}$ & $36.6 \pm 1.7 \mathrm{~cm}^{\mathrm{c}}$ & $\mathrm{P}<0.0001$ \\
& $\mathrm{BCS}$ & $2.7 \pm 0.3^{\mathrm{a}}$ & $3.2 \pm 0.3^{\mathrm{b}}$ & $3.3 \pm 0.6^{\mathrm{b}}$ & $\mathrm{P}=0.0988$ \\
& $\mathrm{~N}$ & 6 & 55 & 53 & \\
\hline$>48$ months & $\mathrm{PE}$ & $31.3 \pm 1.1 \mathrm{~cm}^{\mathrm{a}}$ & $34.8 \pm 1.0 \mathrm{~cm}^{\mathrm{b}}$ & $38.6 \pm 1.7 \mathrm{~cm}^{\mathrm{c}}$ & $\mathrm{P}<0.0001$ \\
& $\mathrm{BCS}$ & $3.0 \pm 0.4^{\mathrm{a}}$ & $3.3 \pm 0.5^{\mathrm{b}}$ & $3.4 \pm 0.5^{\mathrm{c}}$ & $\mathrm{P}=0.0003$ \\
& $\mathrm{~N}$ & 61 & 428 & 499 & \\
\hline
\end{tabular}

a,b,c: different lowercase letters in the same line indicate $\mathrm{P}<0.05 ; \mathrm{A}, \mathrm{B}$ : different capital letters in the same line indicate $\mathrm{P}<0.10$; Q1Q2 = animals considered questionable in Table 1 (Fonseca et al., 1997) and in Table 2 (Fonseca et al., 2020); A1Q2 = animals considered approved in Table 1 (Fonseca et al., 1997) and questionable in Table 2 (Fonseca et al., 2020); A1A2 = animals considered approved in Table 1 (Fonseca et al., 1997) and in Table 2 (Fonseca et al., 2020). 
As observed in Table 3, using the updated table (Table 2) for the field selection of sire reproductive potential, a total of $47 \%$ of the animals (regardless of age) would not have reached the ideal classification parameters. In other words, if the criteria for bull selection were based on the former table (Table 1), a total of $94 \%$ $(n=1184)$ of them would be maintained on the property for the distribution of their genes at the next breeding season. In contrast, if the property adopted a more rigorous selection criterion (approving animals based on Table2), only 53\% $(n=664)$ of the animals would be maintained in the farm reproductive program.

Thus, the use of higher challenge criteria contributes to genetic herd improvement because it reduces the use of bulls presenting lower reproductive potential, which reduces production costs. Additionally, despite the unquestionable economic importance of using selected animals with higher reproductive potential, it is still important to emphasize the possibility of including a greater number of cows per bull, rather than the traditionally used reason of 25:1 (Fonseca et al., 2020). Moreover, in Table 3, it was interesting to observe higher $(\mathrm{P}<0.0001) \mathrm{PE}$ in A1A2 bulls compared to bulls from other categories (Q1Q2 and A1Q2) in all age ranges. This difference precisely illustrates the genetic evolution obtained in PE parameter for Nellore breed considering this important selection criteria over the years.

The use of PE criterion for selecting Zebu animals could be questioned (Caldas et al., 1999; Unanian et al., 2000), since the predominance of testicles of long shape in Bos indicus (Siqueira et al., 2012) could suggest that testicular volume (VT) was a reproductive parameter more appropriate (than PE) for selection of animals with increased precocity and reproductive performance (Siqueira et al., 2013). If so, some Nellore bulls with long testicles could be eliminated due to this racial pattern because they might present smaller PE than their contemporaries with oval testicles (Unanian et al., 2000). However, positive and highly accurate genetic relationships between VT and PE indicated that the latter is an appropriate characteristic for predicting testicle size in Nellore bulls, and should be adequately used in selection programs for this breed (Dias et al., 2008).
Additionally, other authors (Quirino et al., 1999; Sesana et al., 2007; Dias et al., 2008) have shown that bulls with larger PEs have greater testicular volume and body weights. These findings imply that selection for reproductive characteristics based on PE is positively and directly related to selection for VT, sexual precocity and ponderal development, as well as for several other indirect reproductive and productive progress (Siqueira $e t$ al., 2013). Another interesting aspect to be observed in Table 3 was the results of BCS according to bulls' categories Q1Q2, A1Q2 and A1A2. Statistical tendency $(\mathrm{P}<0.10)$ and/or statistical differences $(\mathrm{P}<0.05)$ of higher $\mathrm{BCS}$ were observed in animals with better andrological classifications in several age groups. This is an important indication that, besides the evidenced improvement in reproductive precocity, a careful selection for animals with higher PE also contributes for selection of animals with greater weight development efficiency, an extremely desirable factor in beef industry.

Early body growth increases weight gain efficiency and presents strong influence on herd profitability. Favorable genetic correlations between PE and body weight traits have been described in several studies (Koots et al., 1994; Bergmann et al., 1996; Eler et al., 1996; Lôbo, 1998; Quirino et al., 1999; Dias et al., 2008; Devkota et al., 2008; Lira et al., 2008), which demonstrates a common genetic basis between these characteristics (Siqueira et al., 2013). Moreover, it indicates compatibility for body growth and fertility in the Nellore selection programs (Dias et al., 2008). Salvador et al. (2002) highlights that the positive high correlation between bovine PE and body weight suggests that $\mathrm{PE}$ is also an indicative parameter for identifying bulls with greater weight gain potentials, corroborating our findings.

Still, besides the higher PE observed in A1A2 category compared to A1Q2 in all age groups, it is also noteworthy that the mean PE of $33.4 \mathrm{~cm}$ achieved by pubertal animals (18-24 months) of A1A2 category is similar to the average PE (32.9 $\mathrm{cm}$ ) achieved for adult animals (36-48 months) approved only in the antique table (category A1Q2). Such results illustrate and emphasize the notoriety of andrological examination for field sire selection and confirm the high repeatability and heritability of PE (Fonseca et al., 2019). Satisfactory semen characteristics of sperm 
motility and morphology usually present favorable correlations with testicular development, which denotes the importance of PE also for these parameters (Siqueira et al., 2013;
Fonseca et al., 2019). The data of semen characteristics for each classification category according to age groups are demonstrated in Table 4.

Table 4. Mean ( \pm Standard Deviation) of sperm motility (Mot), vigor (V), major defects (DMa), minor defects (dme) and total sperm defects (TDE) of 1257 Nellore bulls submitted to field andrological examination based on classification tables proposed by Fonseca et al. 1997, 2020

\begin{tabular}{|c|c|c|c|c|}
\hline Age group & Parameter & Q1Q2 & $\mathrm{A} 1 \mathrm{Q} 2$ & $\mathrm{~A} 1 \mathrm{~A} 2$ \\
\hline \multirow[t]{6}{*}{18 to 24 months } & Mot & $\mathrm{X}$ & $55.0 \pm 14.3 \%$ & $47.1 \pm 15.4 \%$ \\
\hline & Vigor & $\mathrm{X}$ & $2.99 \pm 0.67$ & $2.94 \pm 1.05$ \\
\hline & Dma & $X$ & $2.78 \pm 1.30$ & $3.20 \pm 2.58$ \\
\hline & Dme & $\mathrm{X}$ & $2.00 \pm 2.06$ & $4.00 \pm 3.81$ \\
\hline & TDE & $\mathrm{X}$ & $4.8 \pm 1.9 \%$ & $7.2 \pm 5.2 \%$ \\
\hline & $\mathrm{N}$ & 0 & 10 & 34 \\
\hline \multirow[t]{6}{*}{24 to 36 months } & Mot & $45.1 \pm 19.4 \%$ & $57.4 \pm 17.0 \%$ & $55.1 \pm 13.6 \%$ \\
\hline & Vigor & $2.70 \pm 0.84$ & $3.18 \pm 0.75$ & $2.96 \pm 0.71$ \\
\hline & Dma & $2.33 \pm 2.31$ & $3.75 \pm 3.21$ & $3.57 \pm 2.46$ \\
\hline & Dme & $3.67 \pm 2.52$ & $4.54 \pm 2.77$ & $3.79 \pm 3.37$ \\
\hline & TDE & $5.6 \pm 4.7 \%$ & $8.3 \pm 4.3 \%$ & $7.4 \pm 4.4 \%$ \\
\hline & $\mathrm{N}$ & 6 & 27 & 78 \\
\hline \multirow[t]{6}{*}{36 to 48 months } & Mot & $63.3 \pm 8.2 \%{ }^{\mathrm{AB}}$ & $58.1 \pm 8.9 \%^{\mathrm{A}}$ & $61.2 \pm 12.8 \%^{\mathrm{B}}$ \\
\hline & Vigor & $2.83 \pm 0.52$ & $3.23 \pm 0.74$ & $3.24 \pm 0.85$ \\
\hline & Dma & $2.33 \pm 1.51$ & $3.42 \pm 1.75$ & $3.77 \pm 2.37$ \\
\hline & Dme & $2.10 \pm 1.79$ & $3.50 \pm 3.14$ & $4.23 \pm 3.20$ \\
\hline & TDE & $4.3 \pm 3.0 \%$ & $6.9 \pm 3.6 \%$ & $8.0 \pm 3.9 \%$ \\
\hline & $\mathrm{N}$ & 6 & 55 & 53 \\
\hline \multirow[t]{6}{*}{$>48$ months } & Mot & $50.2 \pm 17.4 \%^{\mathrm{a}}$ & $55.5 \pm 14.7 \%^{b}$ & $55.8 \pm 12.2 \%^{b}$ \\
\hline & Vigor & $2.77 \pm 0.82^{\mathrm{a}}$ & $3.21 \pm 0.82^{\mathrm{b}}$ & $3.23 \pm 0.81^{\mathrm{b}}$ \\
\hline & Dma & $2.37 \pm 2.37$ & $3.22 \pm 2.35$ & $3.02 \pm 2.37$ \\
\hline & Dme & $3.47 \pm 3.45$ & $2.85 \pm 2.73$ & $3.09 \pm 2.74$ \\
\hline & TDE & $5.8 \pm 3.8 \%$ & $6.1 \pm 3.7 \%$ & $6.1 \pm 3.8 \%$ \\
\hline & $\mathrm{N}$ & 61 & 428 & 499 \\
\hline
\end{tabular}

a,b: different lowercase letters in the same line indicate $\mathrm{P}<0.05 ; \mathrm{A}, \mathrm{B}$ : different capital letters in the same line indicate $\mathrm{P}<0.10$; $\mathrm{Q} 1 \mathrm{Q} 2$ = animals considered questionable in table 1 (Fonseca et al., 1997) and in table 2 (Fonseca et al., 2020); A1Q2 = animals considered approved in table 1 (Fonseca et al., 1997) and questionable in table 2 (Fonseca et al., 2020); A1 A2 = animals considered approved in table 1 (Fonseca et al., 1997) and in table 2 (Fonseca et al., 2020).

It can be observed in Table 4 that, in the age group $>48$ months, higher values for sperm motility $(\mathrm{P}=0.0250)$ and vigor $(\mathrm{P}=0.0335)$ were observed in animals A1Q2 and in animals A1A2 compared to Q1Q2 category. Additionally, statistical tendency $(\mathrm{p}=0.0741)$ for higher motility was identified in the age 36-48 months, for A1A2 animals (which were approved in the most updated classification table and went through a more rigorous selection criterion) compared to A1Q2. The low number of animals belonging to Q1Q2 category in this age group did not allow further conclusions regarding to it.

Similarly, the literature demonstrates positive correlation with reproductive potential and semen production traits (Bergman et al., 1996; Ahmad et al., 2010; Ayala et al., 2016) and implies that bovine sires with greater testicular development are genetically more prone to present increased sperm motion characteristics and reduced sperm defects (Quirino et al., 1999; Dias et al., 2008). Thus, bull selection based on PE may leads to favorable indirect selection for semen characteristics (Siqueira et al., 2013). Therefore, in this work it was possible to verify that the classification tables used in the field must evolve as the genetic improvement has been improved, reinforcing the importance and the need to increase the requirements of the andrological parameters of Nellore bulls, as it allows the selection of superior sires. Meticulous bull 
selection provides greater benefits for the breed, as they contributes for higher fertility rates and additive genetic gains. Hence, putting the information here provided all together, this work highlights the importance of updated requirements in BSE classification tables for the further development of Nellore reproductive and productive potential as well as field genetic improvement.

\section{CONCLUSION}

Breeding soundness examination using stricter and narrow parameters for bull classification has a positive effect on productive and reproductive variables. It is a low-cost management practice and, thus, an inexpensive tool for technology implementation on the beef cattle production system. It contributes to increasing calf quality and calf production and generates positive impacts on the overall beef production chain. Animals approved at breeding soundness examination using the most updated and strict classification table presented higher scrotal perimeter and better body condition score, as well as adequate semen parameters, regardless of age. Thus, the results here presented denote an evident advance of Nellore genetic improvement in the reproductive aspect and demonstrate that the evolution of classification tables (always demanding updated and higher indexes) is a fundamental tool for further development of reproductive potential of Nellore bulls in the field.

\section{REFERENCES}

AHMAD, N.; UMAIR, S.; SHAHAB, M. et al. Testicular development and establishment of spermatogenesis in Nili-Ravi buffalo bulls. Theriogenology, v.73, p.20-25, 2010.

AYALA, H.D.M.; RIBEIRO, H.F.L.; ROLIM FILHO, S.T. et al. Association of testicular echogenicity, scrotal circumference, testicular volume and testosterone concentration in buffaloes. Rev. Bras. Med. Vet., v.38, p.334-340, 2016.

BERGMANN, J.A.G.; ZAMBORLINI, L.C.; PROCÓPIO, C.S.O. et al. Estimativas de parâmetros genéticos do perímetro escrotal e do peso corporal em animais da raça Nelore. Arq. Bras. Med. Vet. Zootec., v.48, p.69-78, 1996.
BLOM, E. The ultrastructure of same charactheristics sperm defects and a proposal of a new classification of bull spermiogram. Nord. Vet. Med., v.25, p.383-391, 1973.

CALDAS, M.E.; PINHO, T.G.; PINTO, P.A. et al. Avaliação da biometria e morfologia testicular de touros jovens da raça Nelore (Bos Taurus indicus). Rev. Bras. Reprod. Anim., v.23, p.210212, 1999.

DEVKOTA, B.; KOSEKI, T.; MATSUI, M. et al. Relationships among age, body weight, scrotal circumference, semen quality and pheriperal testosterone and estradiol concentrations in pubertal and postbubertal Holstein bulls. J. Vet. Med. Sci., v.70, p.119-121, 2008.

DIAS, J.C.; ANDRADE, V.J.; MARTINS, J.A.M. et al. Correlações genéticas e fenotípicas entre características reprodutivas e produtivas de touros da raça Nelore. Pesqui. Agropecu. Bras., v.43, p.53-59, 2008.

ELER, J.P.; FERRAZ, J.B.S.; SILVA, P.R. Parâmetros genéticos para peso, avaliação visual e circunferência escrotal na raça Nelore, estimados por modelo animal. Arq. Bras. Med. Vet. Zootec., v.48, p.203-213, 1996.

ELER, J.P.; SILVA, J.A.I.V.; EVANS, J.L. et al. Additive genetic relationships between heifer pregnancy and scrotal circumference in Nellore cattle. J. Anim. Sci., v.82, p.2519-2527, 2004.

FONSECA, V.O.; FRANCO, C.S.; AZEVEDO, N.A. et al. Potencial reprodutivo (PR) de touros Nelore avaliados por parâmetros andrológicos e comportamento sexual. Classificação por pontos: nova proposição. Arq. Bras. Med. Vet. Zootec., v.72, p.1102-1112, 2020.

FONSECA, V.O.; SANTOS, N.R.; MALINSKI, P.R. Classificação andrológica de touros zebus com base no perímetro escrotal e características morfo-físicas do sêmen. Rev. Bras. Reprod. Anim., v.21, p.36-39, 1997.

FONSECA, V.O.; SOUZA, C.F.; AZEVEDO, N.A. et al. Parâmetros reprodutivos de touros Nelore (Bos taurus indicus) criados a pasto de diferentes faixas etárias. Arq. Bras. Med. Vet. Zootec., v.71, p.385-392, 2019. 
HOUGHTON, P.L.; LEMENAGER, R.P.; MOSS, G.E. et al. Prediction of postpartum beef cow body composition using weight to height ratio and visual body condition score. J. Anim. Sci., v.68, p.1428-1437, 1990.

KOOTS, K.R.; GIBSON, J.P.; WILTON, J.W. Analyses of published genetic parameter estimates for beef production traits: 2. Phenotypic and genetic correlations. Anim. Breed. Abstr., v.62, p.825-853, 1994.

LIRA, T.; ROSA, E.M.; GARNERO, A.V. Parâmetros genéticos de características produtivas e reprodutivas em zebuínos de corte (revisão). Ciênc. Anim. Bras., v.9, p.1-22, 2008.

LÔBO, R.N.B. Genetic parameters for reproductive traits of zebu cows in the semiarid region of Brazil. Livest. Prod. Sci., v.55, p.245248, 1998.

MANUAL para exame andrológico e avaliação de sêmen animal. 3.ed. Belo Horizonte: CBRA, 2013. 104p.

MENEGASSI, S.R.O.; BARCELLOS, J.O.J.; LAMPER, V.N.; BORGES, J.B.S.; PERIPOLLI, V. Bioeconomic impact of bull breeding soundness examination in cow-calf systems. Rev. Bras. Zootec., v.40, p.441-447, 2011.

PEREIRA, E.; ELER, J.P.; FERRAZ, J.B.S. Análise genética de características reprodutivas na raça Nelore. Pesqui. Agropecu. Bras., v.37, p.703-708, 2002.

PINTO, P.A.; SILVA, P.R.; ALBUQUERQUE, L.G. et al. Avaliação da biometria testicular e capacidade de monta em bovinos das raças Guzerá e Nelore. Rev. Bras. Reprod. Anim., v.13, p.151-156, 1989.

QUIRINO, C.R.; BERGMANN, J.A.G.; VALE FILHO, V.R. et al. Evaluation of four mathematical functions to describe scrotal circumference maturation in Nellore cattle. Theriogenology, v.52, p.25-34, 1999.

SALVADOR, D.F.; DIAS, J.C.; VALE-FILHO V.R. et al. Perfil Andrológico de Touros da raça Nelore com três e quatro ano de idade, criados extensivamente em condições do estado do Mato Grosso do Sul. Rev. Bras. Reprod. Anim., v.26, p.64-65, 2002.
SESANA, R.C.; ALBUQUERQUE, L.G.; SILVA, J.A.V. et al. Estimativas de herdabilidade e correlação genética do perímetro escrotal, medido em diferentes idades, em animais Nelore. In: REUNIÃO DA SOCIEDADE BRASILEIRA DE ZOOTECNIA, 44., 2007, Jaboticabal. Anais... Jaboticabal: FCAV/UNESP-SBZ, 2007.

SILVA, O.E.D.F.; UNANIAN, M.M.; CORDEIRO, C.M.T. et al. Relação da circunferência escrotal e parâmetros da qualidade do sêmen em touros da raça Nelore, PO. Rev. Bras. Zootec., v.31, p.1157-1165, 2002.

SIQUEIRA, J.B.; GUIMARÃES, J.D.; PINHO, R.O. Relação entre perímetro escrotal e características produtivas e reprodutivas em bovinos de corte: uma revisão. Rev. Bras. Reprod. Anim., v.37, p.3-13, 2013.

SIQUEIRA, J.B.; OBA, E.; PINHO, R.O. et al. Testicular shape and andrological aspects of young Nellore bulls under extensive farming. Rev. Bras. Zootec., v.41, p.612-617, 2012.

UNANIAN, M.M.; SILVA, A.E.D.F.; MCMANUS, C. et al. Características biométricas testiculares para avaliação de touros zebuínos da raça Nelore. Rev. Bras. Zootec., v.29, p.136-144, 2000

VALE FILHO, V.R. Subfertilidade em touros jovens e erados: parâmetros para avaliação andrológica e conceituação geral. Cad. Tecn. Vet. Zootec., v.35, p.81-87, 2001.

VALE FILHO, V.R.; ANDRADE, V.J.; AZEVEDO, N.A. Avaliação andrológica e seleção de tourinhos zebu para reprodução. Anais do VII SIMPÓSIO INTERNACIONAL DE PRODUÇÃO DE GADO DE CORTE, Viçosa, 7., 2010. Viçosa: SIMCORTE, p.363-412,

VIU, M.A.O.; MAGNABOSCO, C.U.; FERRAZ, H.T. et al. Desenvolvimento ponderal, biometria testicular e qualidade seminal de touros Nelore (Bos taurus indicus) criados extensivamente na região Centro-Oeste do Brasil. Arch. Vet. Sci., v.11, p.53-57, 2006.

WILLET, E.L.; OHMS, J.I. Measurement of testicular size and its relations to reproduction of spermatozoa by bulls. J. Dairy Sci., v.40, p.15591569, 1975. 